\title{
A longitudinal study of twins from birth to adulthood
}

\author{
Anne Mari Korbøl Torgersen \\ Department of Psychology, University of Oslo, Norway \\ Correspondence: a.m.torgersen@psykologi.uio.no
}

\begin{abstract}
Temperamental variation in infancy was the starting point for this longitudinal study of twins followed from birth to adulthood. The influence of early individuality on later development was a research question in the follow-ups, and by choosing twins as a group, it was possible to uncover the effect of environmental and genetic factors at the different ages. Developmental psychopathology turned out to be a relevant framework, where mental health and well-being are seen as the result of a continuous transaction between geneticallybased individuality and a changing and varying environment (Maughan \& Rutter, 2008). The twin method was an adequate tool to gain a better understanding of these processes. The overall clear message from the study is that whereas heritability of temperament can be seen from infancy on, environmental factors are of crucial importance for an understanding of mental development and health, but the effect of environmental factors probably varies a great deal in dependency upon the genetic disposition of the person.
\end{abstract}

This is an open access article distributed under the Creative Commons Attribution Licence, which permits unrestricted use, distribution, and reproduction in any medium, provided the original work is properly cited.

\section{INTRODUCTION}

Contrary to most longitudinal twin studies described in today's literature, where a large number of twins are seen by a large number of professionals, this longitudinal twin study examines only one small group of 53 pairs of twins born in 1969 and 1970 and seen mainly by one person (the person who conducted this study and authored this contribution).

Within developmental psychology, as within social sciences in general (Kuhn, 1962), there was a paradigm shift in the late 1960s from linear to transactional explanation models of development. Central, often cited articles at the time claimed that the child's individuality contributes to its own development through transactional processes with the environment (Bell, 1968; Thomas and Chess, 1968). This way of thinking gave rise to new sorts of longitudinal studies where behavioral individuality was focused (Lerner, 2002). Earlier well known longitudinal studies on child development, as conducted by Nancy Bayley, or Arnold Gesell, both started in the 1930s, typically focused on normative development: What is the normal stage of development of a child at each age? The New York Longitudinal Study (NYLS) started by Thomas and Chess and their colleagues in 1956 (Thomas et al, 1963) focused on variation in behavior from infancy on as an input to the transactional processes with the environment throughout development.

Thomas and Chess underlined that already in infancy, the norm was to be different also in behavior, which they initially called "primary reaction pattern" or "initial reactivity". They eventually identified nine different behavior styles along which infants were normally distributed, which they later called "temperament", and by this pioneered the systematic applications of temperament concepts to measurement of children's individuality. Although Thomas and Chess focused on temperamental individuality from infancy, they did not say anything about the reasons for the variations. Were they inherited?

If temperament was inherited, genetic variation had to be controlled for in developmental studies. The best way to do this would be with the twin method. In fact longitudinal twin studies became very popular from the 1970s on, first to test the genetic hypothesis and then to study environment with a control of genetic factors (Plomin \& Rutter, 1989).

Together with the technical and computerized revolutions of the last 30 to 40 years, and the new knowledge within behavior genetics and epigenetics, questions as well as methods have changed considerably within twin research (Rutter, 2006). The presentation of this small-scaled twin study might be of mainly historic interest. However, the details and close-up personal information might give rise to collaboration in forming hypotheses.

Results and specific methods from the different age levels studied will be presented, all embedded in the relevant research questions and the methods available at the time. Only some of the most important results of specific interest for twins or twin research are reported, partly due to lack of space and partly due to the lack of publications. Some important results are mentioned, however, although they were only presented at international conferences.

\section{GENERAL AIMS OF THIS STUDY}

In this longitudinal setting, each age period studied, from infancy through early childhood and adolescence to adulthood, had a different focus. As a starting point, interest centered on observable individual differences in infants' reactivity and behavior. Preventive work in infant-mother health care was in its beginnings in Norway in the 1960s (Bogen et al, 1972). Could we give the mothers advice rather than base our psychological work on repair? But since infants are so different, the 
preventive advice had to vary as well. What works for one child does not seem to work for another. Why do children react so differently to the same stimulation, and why are some infants easy to soothe and others so difficult? Why do two siblings in the same family have such different reactions to the same surroundings? To be able to give advice, we wanted to understand the variation in infants' behavior.

Overall, of interest was the degree to which early individuality was influenced by genetic factors, and how individual differences present from infancy on might influence later development, to different extents at different age levels. When personality was studied in the adult follow-up, there was less focus on the heritability question, since several large-scale twin studies had already verified this (Jang et al, 1996). Instead, the twin method was used to obtain information on environmental factors.

\section{MATERIALS AND METHODS}

\section{The twins}

The 53 pairs of twins studied comprised the total group of same-sex twins born during an 18-month period in 1969 and 1970 in the regional hospital in a medium-sized Norwegian city, which served also the surrounding countryside. All the mothers at the birth clinic agreed to participate in the study. Consequently, it was an unselected sample, and the usual distribution of social classes in Norway was found. Parents varied in education and work, from unemployed, to living on social welfare, to well-off academics. The families varied also in their living conditions, from remote islands and inner fjords, to small farms in the mountains, to suburban apartments and houses in the inner city area. In adulthood, the twins lived all around the country and some also abroad.

To determine the twins' zygosity, blood tests (11 systems) were performed on blood from the umbilical cords of all twins (Torgersen \& Kringlen, 1978). Thirty-five of the twin pairs were eventually identified as monozygotic (MZ) and 17 as dizygotic (DZ) on the basis of blood and serum typing and on supplementary descriptions of the twins' physical similarity as reported on parent questionnaires (Torgersen, 1981a). Table 1 shows the number of MZ and DZ twin pairs available for each age studied. About equal numbers of the twin pairs were boys and girls.

Table 1. Number of twin pairs and their zygosity at each age studied.

\begin{tabular}{ll}
\hline Age of twins & $\begin{array}{l}\text { Number of twin pairs, } \\
\text { and their zygosity }\end{array}$ \\
\hline 2-4 days after birth & $53(34 \mathrm{MZ}, 16 \mathrm{DZ})$ \\
2 months & $53(34 \mathrm{MZ}, 16 \mathrm{DZ})$ \\
9 months & $53(34 \mathrm{MZ}, 16 \mathrm{DZ})$ \\
6 years & $48(32 \mathrm{MZ}, 16 \mathrm{DZ})$ \\
15 years & $44(29 \mathrm{MZ}, 15 \mathrm{DZ})$ \\
30 years & $45(30 \mathrm{MZ}, 15 \mathrm{DZ})$ \\
\hline
\end{tabular}

Statistically, the number of MZ versus same-sex DZ twins was expected to be the same (Stern, 1972). The argument for the different numbers found in this study sample to have occurred by chance is discussed in an early paper (Torgersen \& Kringlen, 1978).

Attrition up to the 30-year follow-up was due to death of one or both twins in five pairs. Some twins, whose parents withdrew from the study at child age 6 or 15 years, participated in the study again as adults. Only three pairs chose not to participate in the study at the 30-year follow-up.

\section{Temperament in focus}

In 1969, the study interest was in infants' behavioral individuality. The concept of temperament proposed by Thomas et al $(1963,1977)$ and used in their NYLS was at the time a new and promising way of assessment using a reliable interview method. Thomas and Chess defined temperament as "behavioral style"; dimensions of temperament refer to the "how" rather than the "why" (motivation) and "what" (content) of behavior (1977, p. 9). Analysis of the NYLS interview protocols resulted in nine different behavior dimensions along which infants could be rated (Table 2). Thomas and Chess assumed that some children would be easier to raise; some would more readily develop behavior problems dependent on their individual temperament style (Thomas et al, 1968). Their "goodness of fit" hypothesis (Thomas \& Chess, 1980, p. 90) assumed that it was both the child's individuality and the mother's responses in mutual interaction that influenced the child's development.

The nine temperament dimensions described by Thomas and Chess were for years used as a model and a starting point for a research tradition on childhood temperament. Several different theories and definitions were subsequently developed, as well as a large variation of different temperament categories (Torgersen, 1990, Rothbart \& Bates, 2006, Caspi \& Shiner, 2008).

\section{SPECIFIC AIMS OF THE STUDY AT THE DIFFERENT AGES}

\section{Infants (1969-70)}

Two main questions were asked in the infant study: How early in infancy is it possible to find a normal distribution of the nine temperamental categories defined by Thomas and Chess: As early as at two months? Furthermore, is the reported temperamental individuality in infancy influenced by genetic factors?

\section{Age 6 (1975-76)}

What is the possible genetic influence on the temperament dimensions at child age 6 years? Do environmental factors have different effects on the individual temperamental variables in infancy compared to age 6 years? It was a known fact that even cognitive ability/ intelligence was difficult to follow as a continuum from infancy to early childhood. Would the same be true also for temperament, or would we find temperamental stability from infancy to age 6 ? 
Table 2. Nine temperament dimensions (Thomas et al. 1963).

\begin{tabular}{|c|c|}
\hline Activity & $\begin{array}{l}\text { The motor component present in a given child's functioning, and the diurnal proportion of active } \\
\text { and inactive periods. }\end{array}$ \\
\hline Regularity & $\begin{array}{l}\text { The predictability and/or the unpredictability in time of any function was analyzed in relation to the } \\
\text { sleep-wake cycle, hunger, feeding pattern, and elimination schedule. }\end{array}$ \\
\hline Approach or withdrawal & The nature of the initial responses to new stimuli: people, situations, places, foods, toys, procedures. \\
\hline Adaptability & $\begin{array}{l}\text { Responses to new or altered situations. Not the nature of the initial responses but the frequency with } \\
\text { which they were successfully modified in desired directions. }\end{array}$ \\
\hline Intensity of reaction & The energy level of a response, irrespective of its quality or direction. \\
\hline Sensory threshold & $\begin{array}{l}\text { The intensity level of stimulation necessary to evoke a discernible response, irrespective of the } \\
\text { specific form that the response might take or the sensory modality affected. The behaviors utilized } \\
\text { were those concerning reactions to sensory stimuli, environmental objects, and social contact. }\end{array}$ \\
\hline Quality of mood & $\begin{array}{l}\text { The amount of pleasant, joyful, and friendly behavior, as contrasted with unpleasant, crying, and } \\
\text { unfriendly behavior. }\end{array}$ \\
\hline Distractibility & $\begin{array}{l}\text { The effectiveness of extraneous environmental stimuli in interfering with, or in altering the direction } \\
\text { of, on-going behavior. }\end{array}$ \\
\hline $\begin{array}{l}\text { Attention span and } \\
\text { persistence }\end{array}$ & $\begin{array}{l}\text { Attention span is the length of time a particular activity is pursued by the child. Persistence refers to } \\
\text { the continuation of an activity in the face of obstacles to the maintenance of the activity direction. }\end{array}$ \\
\hline
\end{tabular}

\section{Age 15 (1985-86)}

Although it was generally accepted at the time that genetic factors had a great influence on temperamental individuality, a large part of the variation was reported to be based on environmental differences (Plomin, 1986). Individual differences in temperamental behavior were reported to be best shown in stress situations (Suomi, 1987, Chess and Thomas, 1984). Could stress explain some of the differences found in MZ twin pairs? Such differences would tell us about environmental influence in spite of genetic similarity.

\section{Age 30 (1999-2000)}

Individual differences were at this age not measured as temperament but as personality. Behavioral geneticists had already concluded that there was a strong influence of genetic factors on personality variation (Jang et al, 1996). Environmental factors affecting personality were primarily of the nonshared type, which could be measured directly as differences found within $\mathrm{MZ}$ twin pairs (Plomin, 1986). A central aim of the followup at age 30 was to objectively register environmental factors, in order to shed light on reasons for withinpair differences in personality and well-being found in MZ twin pairs. Different experiences of the environment were supposed to be found within: relations with one's twin; relations with parents; and different experiences of stress factors.

\footnotetext{
All ages

Predictions of behavior problems and psychological well-being from one age to the others, and the association between temperament and different symptoms were examined at all ages, as was the case with the relations between the two twins in a pair. To what degree was well-being related to the relations between the twins and relations with their parents?
}

\section{Data collection}

The first interviews with the mother were completed at the birth clinic a few days after the birth. During a rather short visit, the mother was invited to talk about the experience of having twins, her expectations, and her health situation. The hospital journals as well as observations by the midwives supplied background information on pregnancy and delivery details for each of the twins (Torgersen, 1985).

Data were later collected by means of semistructured interviews with the mothers, conducted at each of the four ages from infancy to age 15 at their homes, which I reached by car, ferries, and even a small air plane. The home visits lasted 4 to 5 hours and included in addition to the interview also observation of daily routines and the child's everyday behavior. From the age of 15 , the twins were also interviewed separately. Over the years and throughout the long visits, a relation was established between me and the twins and the mothers that could be described as open, close and professional. At the 30-year follow-up, the twins were one by one invited to an interview at my office lasting 3 to 4 hours. Each twin filled out a number of questionnaires at home before and after the visit.

Measurement and rating of temperament and personality. Information on the twin's temperament was obtained by the interview with the mother. Great care was taken to mainly ask for descriptions of the child's behavior and not for the mother's evaluations. All interviews were tape recorded and transcribed in detail by a secretary who had no knowledge of the twins and their zygosity.

With the infants, it was possible to cover most of the daily situations in the child's life using an interview guide developed by Thomas et al (1963). Neither the interviewer nor the parents knew the twin's zygosity before all interviews (blinded for names and several 
months after the interviews) were scored for temperament by this author. The scoring principles used in the NYLS were modified for more detailed scoring, and a control scoring was made by the scorers of the NYLS (Torgersen, 1973, Torgersen \& Kringlen, 1978). Attention span was not possible to assess at age 2 months due to lack of relevant reported behavior.

At age 6 years, the interview guide developed by Thomas and Chess (1968) for this age group was used with some modifications (Torgersen 1981a). The interview covered daily activities like eating, sleep, play and activity, relations with twin, relations with parents and friends. The scoring for temperament was undertaken by a person who did not know the twins or their zygosity. In place of the sentence-by-sentence scoring that was done in the infant study, scoring rules were developed where only situations were evaluated that were scorable for most children $(>80 \%)$. In addition, individual items were reduced to those with an acceptable inner factorial consistency within the temperament category (Torgersen 1981a, 1991a). Distractibility was excluded at age 6 during this process.

At age 15 the interview was designed to cover the same categories of behavior as registered at age 6 , with necessary age-appropriate changes (Torgersen, 1987, 1991a). Distractibility and regularity were not possible to score from the interview at this age. The final temperament items used at age 6 and 15 were published as an appendix in a doctoral thesis (Torgersen, 1991a). Each of the twins also filled out a temperament questionnaire, the Dimensions of Temperament SurveyRevised (DOTS-R) (Windle \& Lerner, 1986), which mothers filled out for each of the two twins as well (Torgersen, 1991b).

As a measure of individual differences at age 30, personality was assessed rather than temperament, using the NEO Personality Inventory-Revised (NEOPI-R) (Costa \& McCrae, 1992). The NEO-PI-R questionnaire measures the five major domains of personality (Five Factor model): Neuroticism, Extraversion, Openness, Agreeableness, and Conscientiousness. It has been said that temperament in childhood is comparable to personality in adulthood, although Thomas and Chess would not agree with this definition, since personality also includes motivational aspects which are excluded in their original temperament definition.

Measurement and ratings of relationships. The twins' relationship with each of the parents as well as with each other was assessed as a part of the interview with the mother at all ages in childhood and adolescence. At age 15, this question was also posed in an interview (from 30 minutes to 1 hour in duration) with each twin separately as well as in questionnaires filled out by parents and twins separately.

Relations with parents measured in retrospect at age 30 were assessed by the Adult Attachment Interview (AAI) (Hesse, 1999). The AAI is an instrument developed to assess adults' internal working models with respect to attachment relationships and is supposed to be influenced by experiences in early childhood. This interview lasted for about 90 minutes. It was tape recorded, printed out in detail, and scored by a certified person without knowledge of the twins. Each twin also filled out a questionnaire on adult romantic attachments (ECRI) (Brennan et al, 1998).

Relations with the other twin in the pair was added as part of the AAI interview and scored separately with an extra score named AAT (Adult Attachment to the Twin). The twins' relationships were also assessed through questionnaires. Part of a questionnaire developed by Nancy Segal, used in California State University Twin study (Segal,1998; personal communication) was used to assess dominance and closeness to the twin, experienced currently and in retrospect.

Measurement and ratings of behavior problems. At age 2 and 9 months: Behavior problems were given two scores in infancy, on a 3-point scale from no problem to clear problem, rated based on the interview with the mother and information from the birth clinic: perinatal complications, infant anxiety, and infant problems (in three areas: elimination, eating, sleep).

At age 6: Based on the interview of the mothers and observations of the children, four groups of behavior symptoms were defined: (1) anxiety (social, pain, animal, darkness-thunder-fire, being left alone, diffuse anxiety, other), (2) conduct symptoms (stealing, honesty/lying, disobedience, fighting/hitting, destruction of one's own or others' property), (3) psychosomatic complaints (headache, pain in the body, stomach-ache, frequent nausea and (4) enuresis.

At age 15: Symptoms and behavior problems were assessed by means of a structured interview with the mother, including existence of, duration, and intensity of possible symptoms (Rutter et al, 1976). Sum scores are given within three diagnostic groups: (1) emotional problems, (2) hyperactivity, and (3) conduct disorder, and an additional (4) sum of symptoms score. The twins also completed two scales on depression: Kandel Depression Scale (1982), Satisfaction with Life Scale (Diener et al, 1985).

At age 30: Symptoms of disorders of personality were assessed by a questionnaire on personality disorder measured as continuous variables rather than as categories, the Millon Clinical Multiaxial Inventory III (MCMI-III) reflecting revisions to the DSM-IV (Millon, 1996). Depressive feelings were assessed using the same instruments as at age 15 .

Family situation and stress. Within behavioral genetic research in the 1980 s and 1990 s, environment was mainly referred to as shared or nonshared environment, based on calculated differences and similarities within the two zygosity groups of twins: monozygotic (MZ) and dizygotic (DZ). Nonshared environment was defined as environmental factors making siblings in the same family different, and shared environment was defined as environmental factors responsible for resemblance between family members (Plomin, 1986). Within the present study, stress was 
from the beginning objectively registered rather than calculated.

Amount of perceived stress was registered during the interviews at the three age levels infancy, age 6, and age 15 . The stress component was separated in a "shared (common)" and a "nonshared (individual)" factor. A high "shared (common)" stress score was given "when several major changes in the family's life situation or continuously strain is reported" and were shared by the two twins in the family. Stress were rated as the unweighted averages of a sum score within 8 to 13 age-relevant areas evaluated along 3-point scales from no stress to severe stress. A "nonshared (individual)" stress score, only given at age 15, relied on 5-point difference scores ranging from "Twin 1 much more" to "Twin 2 much more" on 16 different situations experienced separately by the two twins (Torgersen, 1987).

At age 30, stress factors were assessed using a questionnaire and also as part of the semi-structured interview that included the twin's general life situation in the period from the last visit at age 15 .

\section{RESULTS AND CONTEMPORARY DISCUSSIONS}

\section{Infancy}

All temperamental categories except attention span at 2 months could be measured reliably at both 2 and 9 months and were approximately normally distributed (Torgersen, 1973). The most significant result was that MZ twins were more similar than DZ twins on all temperamental dimensions at both ages, suggesting that heritability was an important explanation of the variation. The difference calculated with $\mathrm{F}$ ratio was significant for all dimensions at 9 months but only for three categories at 2 months (Table 3). Regularity was the temperamental dimension with highest genetic influence at 2 months and 9 months. These results were presented at several international conferences from mid 1970s on and taken as support for the transactional model (Torgersen \& Kringlen, 1978).

Table 3. Differences as F ratio between intrapair variances of weighted temperament scores in MZ and DZ at 2 months and 9 months (Torgersen \& Kringlen, 1978).

\begin{tabular}{lcr}
\hline & \multicolumn{2}{c}{ F ratio } \\
\cline { 2 - 3 } Categories & 2 months & 9 months \\
\hline Regularity & $4.98 * * *$ & $12.86 * * *$ \\
Threshold & $2.82^{* *}$ & $9.90^{* * *}$ \\
Approach & 0.83 & $6.77 * * *$ \\
Intensity & $2.55^{*}$ & $5.32 * * *$ \\
Activity & 1.52 & $5.26^{* * *}$ \\
Persistence/Attention span & - & $4.40^{* * *}$ \\
Distractibility & 1.40 & $3.96 * * *$ \\
Mood & 1.54 & $3.31 * *$ \\
Adaptability & 0.57 & $2.28 *$ \\
\hline$* * * \mathrm{p}<0.001$ & & \\
$* * \mathrm{p}<0.01$ & & \\
$* \quad \mathrm{p}<0.05$ & &
\end{tabular}

Environmental influence seemed to be at its most significant levels in the first few weeks and months of life. Degrees of perinatal complications were the same in the two zygosity groups. Both during pregnancy and at birth, the two twins in MZ twin pairs had as well as the two twins in DZ pairs quite different experiences. Since some MZ twin pairs share the placenta, their competition for the same blood supply sometimes has a differentiating influence on MZ twins. Also, during the birth process, independent of zygosity, one of the twins experienced more strain than the other. Birth weight of MZ twins was as different within the pair as in DZ pairs. At age 9 months, the weight of the MZ twins had developed to be very similar, whereas the degree of difference in DZ twin pairs was the same. $\mathrm{MZ}$ twins grow more alike, whereas DZ twins grew in different directions. Also regarding temperament, DZ twins developed in more different directions at 9 months, and MZ twins kept their higher degree of similarity (Torgersen, 1985, 1987).

When asked about their twin's zygosity at the 9month visit, only 3 mothers out of the 34 mothers of MZ twins guessed that their twins were monozygotic. This was not only reassuring support that the mothers were not biased by the knowledge of the twins zygosity, but it also seemed to represent a lifelong tendency in MZ twins themselves and in their relatives to focus on their observable differences rather than on obvious similarities and to consequently think that they are DZ. Parents of DZ twins seemed to have a bias to look at them as similar, more as an attempt to be "fair" to the two children.

Contemporary discussions. In the early 1970s several groups of researchers included temperamental individuality in their studies on infants. However, my twin study was (among) the first to find a clear genetic influence on the nine temperamental dimensions used in the NYLS.

At the time, these results were of great interest internationally, since they supported the theory of the child's individual influence on the transactional processes between mother and child as presented by Bell (1968) and Thomas and Chess (1968): Different children experience different reactions from the same environment.

\section{Age 6}

The varied stability found from 2 to 9 months, and from infancy to age 6 , in the different temperamental dimensions, emphasized the need for age-relevant questions when this method of behavior description is used for assessment. The obvious advantage of the behavior rating method is that the ratings are less biased than ratings based on mothers' general impressions. The drawback is the difficulties in longitudinal studies to compare the same variables from one age to another, since measures of stability and change rarely differentiate between heterotypic and homotypic continuities. Behavior may change in form while still reflecting the same process. 
The genetic influence on temperament was obvious also at age 6. Only regularity and mood did not show significant differences between the two zygosity groups. Activity and Attention span were among the highest differences. The conclusion that the three temperamental variables with the least evidence for genetic influence at age 6 were regularity, adaptability, and mood was of special interest, as these were the same as those identified in NYLS as important variables in risk for behavior difficulties ("difficult child"), suggesting indirectly the importance of environment for problem behavior (Torgersen, 1981a, 1981b).

At a rather small and exclusive international conference on "Temperamental differences in infants and young children" held in London in 1981, the Ciba Foundation symposium chaired by Michael Rutter, I was invited to present my results on genetic influence on temperament. The conclusion of my paper was that although temperament was genetically influenced, it was not the child's temperament but rather how temperament is met that leads to behavior problems. At the same conference Robert Plomin presented the idea of "Nonshared environment," a statistical calculation that shows part of the environment variance to make siblings as different as nonrelated children. Together with A.H. Buss in 1973, Plomin had presented their version of a temperament questionnaire (EASI) based on temperament categories that was also developed based on the NYLS but ended up with the four temperamental categories that they found to be highly genetically influenced. Ronald Wilson presented results from the longitudinal Louisville Twin Study, which found a genetic influence on cognitive development but also on temperament, as measured with parts of Bayley Scales of Infant Development. The papers were later published in an edited symposium volume (see Torgersen, 1982).

Contemporary discussions. In the politically 'red' 1970s, it was not well accepted to talk about heritability in children's behavior, possibly due to the widespread misconception that genetic influence on behavior implies fixity. Genetic explanations of individual variation in behavior were also in contradiction to the behavioristic view of learning, and to psychoanalytic theory claiming that the decisive influence was early experiences with the mother. On the other hand, even though temperament was seen as only one part in the interaction with environment, already at the $1981 \mathrm{Ciba}$ symposium some delegates suggested the use of medicine in order to 'cure' difficult temperament. They forgot the important conclusion that clinically it is the environment that has to be changed in order to give space to each individual.

Parallel to temperament research in the 1970s, attachment studies were growing in numbers. Mary Ainsworth began her studies with children in The Strange Room Situation and concluded from the child's behavior in that situation whether the child had a secure or insecure attachment relationship to mother
(Ainsworth et al, 1978). Since also within the attachment research, it was the child's behavior that was registered, the dispute started between these two research traditions: Is the variation in the child's observed behavior based on temperament and genetic variation, or is it based on degree of sensitivity in the mothers? Eventually, this dispute ended up sometime in the 1980s or 1990s with the answer that both factors are at work. In the quarter of a century since then, lots of research has been performed that confirm this conclusion. However, it is still the nagging question that makes scientists on both sides still believe that they have the best knowledge of "the truth". Today it seems that the research community has its main focus on genetic explanations, whereas clinicians need to focus on what environmental changes work for each individual. A combination is strongly preferred.

\section{Age 15}

Results presented from the 15 year follow-up, typically include predictions from the earlier studied ages. One of the main questions so far was changes in the heritability of temperament at each age. From Figure 1 (Torgersen, 1987) it was concluded that contrary to common expectations, genetic influence does not fade by age, rather it gets more important.

Similar results had been reported from the Louisville Longitudinal Twin Study for heritability of cognitive as well as temperamental development (Wilson, 1983). Weakness in the method and the small sample may give less strength to this conclusion in the present study, but in favor of the conclusion is that this supports similar results from other studies (Plomin \& Rutter, 1989, Goldsmith, 1989).

Activity was among the most genetically influenced variables, both at separate ages and developmentally. The stability of this variable was also high within infancy and between 6 and 15 years when the whole group were considered. That the same was true also to a certain degree for approach was of interest since approach is close to a sociability factor, and also similar to variables assessing reactions to novelty; both factors are also by others found to be genetically influenced (Torgersen 1989, Suomi 1987, Kagan et al, 1987).

The special situation of being a twin at the time of puberty is described in a Norwegian article (Torgersen, 2006). As expected, the girls were about 2 years earlier in their pubertal development than boys, and the MZ twins were arriving to the pubertal peak close in time, compared with the DZ twins, who sometimes had a difference in more than one year. The most striking difference between MZ and DZ twins at the age of puberty was the change of MZ twins' relation to each other. From a common seen very close childhood, they often had a sudden wish to be different. They often choose different clothing, different hairstyle and different friends, as if looking for their personal identity.

A conclusion from the 15 years follow-up, was that when stress was measured rather than calculated, the 

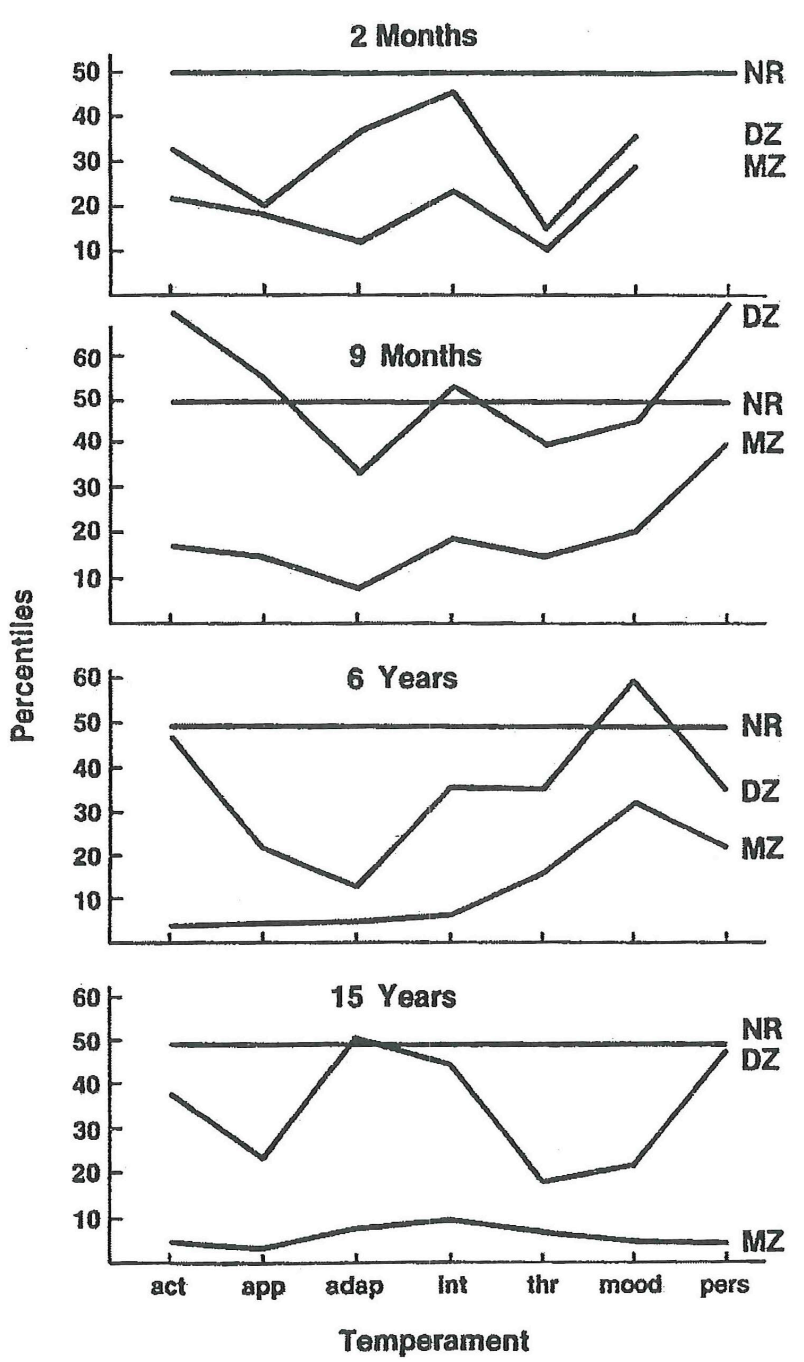

Figure 1. Median within-pair differences in temperament in $\mathrm{MZ}$ and DZ twins and in nonrelative pairs (NR) presented as percentiles of the distribution of within-pair differences in NR (Torgersen 1987, p148). Since attention span at age 2 months and regularity at age 15 years was not possible to assess reliably, it was excluded from this figure.

same environmental influences create differences rather than similarities among family members, and as such had a Nonshared effect, in behavioral genetical terms. In families with high degree of stress, DZ twins, significant more different in temperament, became more different than $M Z$ twins i.e. they reacted more differently to the same situation (Torgersen, 1987, 1989).

Contemporary discussions. Since few studies within behavioral genetics could document the influence of "Shared environment", a common conclusion was that family environment, was of less importance for behavior development (Reiss et al, 2000), while in fact it meant that it was not strong enough to make the same effect in two siblings in the same family. Rather such results tell us something about the importance of a transactional view of development. After the 15 year assessment a paper showing interaction between similar family stress and different outcomes in behavior were published (Torgersen, 1989). The 30 year assessment started with an interest in this topic, and a paper on the subject was finally published with data also from the 30 year follow-up (Torgersen \& Janson, 2002).

\section{Age 30}

Shared and nonshared stress. Personality differences in adult MZ twin pairs were related to familial stress factors shared by the twins in childhood and early adolescence. Twin pairs, who had shared more stressors at ages 6 to 15, tended to be more different in personality at age 30. These differences were significant for the total difference in the Big Five personality dimensions, as well as for the single personality dimensions Openness, Agreeableness, and Conscientiousness. However, when individual MZ twin-pairs, different in degree of symptoms were scrutinized; only differences in marriage made a significant difference in personality. Case examples illustrate the relationship between stress and personality differences, and provide hypotheses for further studies in larger samples (Torgersen \& Janson, 2002).

Adult attachment. When the within-pair differences of attachment representation in MZ and DZ twins were compared using the AAI, the results showed a clear tendency toward $\mathrm{MZ}$ twins to be more concordant than DZ twins, but the within-pair similarity was also high in both zygosity groups. The results suggest, in behavior genetic terms, that heredity as well as shared environment contribute to attachment status in adulthood (Torgersen, Grova \& Sommerstad, 2007). This differs from studies of attachment in infancy and early childhood which are reported to be explained mainly by shared environment and only negligible by genetic factors (Bokhorst et al, 2003), but is more in line with results from studies where adult attachment is measured by questionnaires in relation to romantic partner (Brussoni et al, 2000). Adult attachment is however not directly comparable to attachment in infancy, and also vary with methods used (Torgersen, 2013). Furthermore, the results showed that the distribution of the attachment pattern in twins had the same percentage distribution as reported elsewhere for singletons. Consequently, there was no tendency toward more insecure attachment in twins than in singletons despite early experiences of being a twin and sharing one mother.

The twin relations. The relations between the two twins in $\mathrm{MZ}$ pairs were also looked at developmentally for how it changed from infancy to the age of 15 . Dominance in the twin pair was not related to competence in schoolwork or in sports. The conclusion was that Twin 1 (first born) was more often the dominant one from infancy on, but the dominance pattern changed in content and stability from early childhood to adolescence. The most dominant twin at age 15 was also the most Extrovert in personality at the age of 30 years (Torgersen, 2001, Presentation in ECDPconference, Uppsala).

The twins' attachments to each other, as measured by AAT, had a similar distribution as the AAI catego- 
rizations. The AAT within-pair concordance was significant in $\mathrm{MZ}$ twins but not in $\mathrm{DZ}$, i.e. $\mathrm{MZ}$ twins had a closer attachment to each other than DZ twins. A tendency for $M Z$ twins to get a dismissing score higher than expected was explained with the special relation to the twin (Torgersen \& Grova, 2012).

Contemporary discussions. During the last years the quantitative methods of behavioral geneticists, where the twin method have been used to estimate heritability and environment, seems to lose its major interest. Behavioral genetics still aims to identify genetic and environmental influences underlying individual differences in behavior, but many geneticists have turned their interest to molecular methods. These include genetic association and functional analyses to identify the genes and genetic variation responsible for the familial aggregation highlighted by twin and family studies (van Dongen \& Boomsma, 2012). Also much more sophisticated and multivariate approaches to twin data continue to yield new insights into the interplay of genetic and environmental influences on human health and behavior (Silventoinen, 2014).

Since behavioral traits are typically heterogeneous and affected by multiple, partly overlapping sets of genes, molecular genetic success is either independent of, or negatively correlated with estimated heritability from twin studies. When a behavior trait is found to be highly heritable when it is studied with the quantitative genetic twin method, it has been difficult to replicate this finding within molecular genetic studies (Bakermans-Kranenburg \& van IJzendoorn, 2006). In a developmental perspective explanations gets even more complicated since different genotypes also will have different phenotypes, depending on age and environment, and since a two-way possibility is acknowledged in that environment can affect which alleles might get turned on and off in response to different environmental conditions. Consequently, the obvious, measurable and significant differences in within pair similarities in MZ vs DZ pair of twins, is still of interest in order to understand the psychological implications of genetical variation.

\section{GENERAL DISCUSSION AND CONCLUSIONS}

Each of the follow-ups in this study was set at ages with large developmental spurts or changes in social situation: in infancy huge changes occur from week to week; at six years the toddler change into a school child; at 15 years pubertal influence change the child into an adolescent; and at 30 years great variability occur at the entrance into adulthood.

In periods with large individual variation, developmental tasks typical for the age period is easier to see, and vulnerability is more specific. Children who tend to be genetically different (as DZ twins) in these periods will be more different, and genetically more similar individuals (as MZ twins) will be more similar, if genetic variance are of importance, the question of heritability will be clearer. High or low heritability at one age might tell us something of importance from that age.

Twins and their situation, their similarities and peculiarities, have for me become a central interest in addition to heritability and temperament. Experiences from all the home-visits from infancy to adolescence gave the inspiration to write a book for twins and their parents about twins and their relation to each other from infancy to adolescence (Torgersen, 2004). These experiences together with my clinical expertise have also made it possible for me to be an adviser at the twin parent club in Oslo on a regular basis. During the last 20 years this practice have been performed by answering questions in their magazine (Tvillingnytt), giving lectures for parents or health personnel, and offering guidance as a clinical psychologist to twin parents, but also to adult twins, taking place on average once or twice a month.

Environmental influence, as it may be measured as differences within MZ twin pairs, are today studied mainly through molecular genetic studies, and epigenetics. Narrow specters of hidden details are discovered. In a small scaled study as the present, the narrowness and the details are of another kind. A small group of people rather than groups of several thousand, introspection and qualitative data rather than microscopic measurements and statistical expertise are used. The type of data is different, but in both cases it is a tiny specter of genetic research information picked out of a total real existence, giving a huge amount of data, and as such might show different roads to better understandings on how environmental risk factors may operate.

\section{THE 45 YEAR STUDY AND BEYOND}

In 2015 the twins reached the age of 45 years. A questionnaire has been developed where the relation to the other twin is in focus, as well as descriptions of physical nearness and emotional closeness. Some single individuals are seen to go even more in depth of how the twin-ship may be experienced, and how some of this can be related to early experiences in the childhood, and from the time they grew up. So far only about half of the twins have answered, relatively often only one of the twins in a pair.

It is too early to refer any results, but a preliminary look seems to reveal that when it comes to more serious psychological problems in life, it is the large environmental burdens from early childhood that make severe damage of the life quality for decades. Several stress factors lasting for a long time seem to be much more decisive than temperament or personality, but individual differences might tell us something about type of symptoms that most probably will develop dependent of individuality. 


\section{REFERENCES}

Ainsworth MDS, Blehar MC, Waters E, Wall S (1978). Patterns of attachment. Hillsdale, NJ: Erlbaum.

Bakermans-Kranenburg MJ, van IJzendoorn MH (2006). Gene-environment interaction of the dopamine D4 receptor (DRD4) and observed maternal insensitivity predicting externalizing behavior in preschoolers. Wiley Periodicals, 48, 406-409.

Bell RQ (1968). A reinterpretation of the direction of effects in studies of socialization. Psychol Rev 75: 81-95.

Bogen B, Solum L, Storvik O, Sommerschild H (1972). Helsestasjonen i støpeskjeen: nye muligheter for psykisk forebyggende arbeid. Oslo: Universitetsforlaget.

Bokhorst CL, Bakermans-Kranenburg MJ, Fearon P, van IJzendoorn MH, Fonagy P, Schuengel C (2003). The importance of shared environment in mother-infant attachment security: A behavioral genetic study. Child Dev, 74, 1769-1782.

Brennan KA, Clark CL, Schaver PR (1998). Self- report measurement of adult romantic attachment: An integrative overview. In: J A Simpson, WS Rholes (eds.): Attachment theory and close relationships. New York: Guilford Press: 46-76.

Brussoni MJ, Jang KL, Livesley WJ, MacBeth TM (2000). Genetic and environmental influences on adult attachment styles. Personal Relationships, 7, 283-289.

Caspi A, Shiner R (2008). Temperament and personality. In: M Rutter, D Bishop, D Pine, S Scott, J Stevenson, E Taylor, A Thapar (eds.): Rutter's child and adolescent psychiatry, $5^{\text {th }}$ edn. Oxford: Blackwell: 182-198.

Chess S, Thomas A (1984). Origins and evolution of behavior disorders. New York: Brunner/Mazel.

Costa PT, McCrae RR (1992) Revised NEO Personality Inventory (NEO-PI-R) and NEO Five-Factor Inventory (NEO-FFI) professional manual. Odessa, FL: Psychological Assessment Resources.

Diener E, Emmons RA, Larsen RJ, Griffin S (1985). The Satisfaction With Life Scale. J Pers Assess, 49, 1, 71-75.

Goldsmith HH (1989). Behavior-genetic approaches to temperament. In: GA Kohnstamm, JA Bates, MK Rothbart (eds.): Temperament in childhood. John Wiley \& Sons: 111-132.

Hesse E. (1999). The Adult Attachment Interview: Historical and current perspectives. In: J Cassidy, PR Shaver (eds.): Handbook of Attachment: Theory, research, and clinical applications. New York: Guilford Press: $395-$ 433.

Jang KL, Livesley WJ, Vernon PA (1996). Heritability of the big five personality dimensions and their facets: a twin study. J Pers, 64: 577-591.

Kagan J, Reznick JS, Snidman N (1987). The physiology and psychology of behavior inhibition in children. Child Dev, 58, 1459-1473.

Kandel DB, Davies M (1982). Epidemiology of depressive mood in adolescents. An empirical study. Arch Gen Psychiatry, 39 (10): 1205-1212.

Kuhn TS (1962). The Structure of Scientific Revolutions. International Encyclopedia of Unified Science. Chicago: The University of Chicago Press.

Lerner R (2002). Concepts and theories of human development, $3^{\text {rd }}$ edn. London: Lawrence Erlbaum Associates.

Maughan B, Rutter M (2008). Development and psychopathology: A life course perspective. In: M Rutter, D Bishop, D Pine, S Scott, J Stevenson, E Taylor, A Thapar (eds.): Rutter's child and adolescent psychiatry, $5^{\text {th }}$ edn. Massachusetts: Blackwell Publishing: 160-181.

Millon T (1996). Disorders of personality, DSM-IV and beyond. New York: John Wiley \& Sons.

Plomin R (1986). Development, genetics, and psychology. Hillsdale, NJ: Lawrence Erlbaum.

Plomin R, Rutter M (1989). Quantitative genetics and developmental psychopathology. In: D Ciccetti (ed.): The emergence of a discipline: Rochester Symposium on Developmental Psychopathology. London: Lawrence Erlbaum Associate Publishers.

Reiss D, Neiderhiser E, Hetherington EM, Plomin R (eds.) (2000). The relationship code: Deciphering genetic and social influences on adolescent development. Cambridge: Harvard University Press.

Rothbart MK, Bates J (2006). Temperament. In: W Damon, RM Lerner, N Eisenberg (eds.): Handbook of Child Psychology, Vol 3. Social, Emotional, and personality development, $6^{\text {th }}$ edn. New York: Wiley: 99-166.

Rutter M, Tizard J, Yule W, Graham P, Whitmore K (1976). Research report: The Isle of Wight Studies 19641974. Psychol Med, 6: 313-332.

Rutter M (2006). Genes and behaviour. Nature-nurture interplay explained. Blackwell Publishing.

Silventoinen K, Volanen SM, Vuoksimaa E, Rose RJ, Suominen S, Kaprio J (2014). A supportive family environment in childhood enhances the level and heritability of sense of coherence in early adulthood. Soc Psychiatry Psychiatr Epidemiol, 49 (12): 1951-1960.

Stern C (1972). Principles of Human Genetics. San Francisco: Freeman.

Suomi SJ (1987). Anxiety-like disorders in young nonhuman primates. In R Gittelman (ed.): Anxiety disorders of childhood. New York: Guilford Press.

Thomas A, Chess S, Birch HG, Hertzig ME, Korn S (1963). Behavioral individuality in early childhood. Oxford, UK: New York University Press. 
Thomas A, Chess S, Birch HG (1968). Temperament and Behavior Disorders in Children. New York: New York University Press.

Thomas A, Chess S (1977). Temperament and development. New York: Brunner/Mazel Publishers.

Thomas A, Chess S (1980). The dynamics of psychological development. New York: Brunner/Mazel Publishers.

Torgersen AM (1973). Temperamentsforskjeller hos spedbarn. Deres årsaker, belyst gjennom en tvillingundersøkelse (Master's thesis, in Norwegian). University of Oslo, ISBN 82-569-0099-7.

Torgersen AM, Kringlen E (1978). Genetic aspects of temperamental differences in infants. J Am Acad Child Psychiatry, 17, 433-444.

Torgersen AM (1981a). Genetic factors in temperamental individuality. J Am Acad Child Psychiatry, 20, $701-711$.

Torgersen AM (1981b). Genetic aspects of temperamental development: A follow-up study of twins from infancy to six years of age. In: L Gedda, P Parisi, WE Nance (eds.): Twin Research 3: Intelligence, Personality and Development. Alan R. Liss: 261-268.

Torgersen AM (1982). Influence of genetic factors on temperament development in early childhood. In: R Porter, GM Collins (eds.): Temperament differences in infants and young children. Ciba Foundation Symposium No. 89. London: Pitman Books: 141-154.

Torgersen AM (1985). Temperamental Differences in infants and 6-years old children: A follow-up study of twins. In: J Strelau, FH Farley, E Gale (eds.): The biological bases of personality and behavior. Washington: Hemisphere Publishing Corporation.

Torgersen AM (1987). Longitudinal research on temperament in twins. Acta Genetic Med Gemellol, 36, 145-154.

Torgersen AM (1989). Genetic and environmental influences on temperamental development: A longitudinal study of twins from infancy to adolescence. In S Doxiadis (ed.): Early influences shaping the individual. New York: Plenum: 269-281.

Torgersen AM (1990). Temperament som utviklings-psykologisk begrep. Utvikling av en forskertradisjon. Tidsskrift for Norsk Psykologforening, 27, 889-911 (In Norwegian).

Torgersen AM (1991a). Genetic and environmental influence on temperamental behavior. A longitudinal study of twins from infancy to adolescence (dissertation). University of Bergen, Norway.

Torgersen AM (1991b). Assessing temperamental individuality with the DOTS-R among adolescents. In: AM Torgersen (ed). Genetic and environmental influence on temperamental behavior. A longitudinal study of twins from infancy to adolescence (dissertation) University of Bergen, Norway.

Torgersen AM (2001). Twin relationship in a developmental perspective. Paper presented at: IXth European Conference on Developmental Psychology, Uppsala, Sweden.

Torgersen AM, Janson H (2002). Why do twins differ in personality: Shared environment reconsidered. Twin research, 5, 44-52. Also published in Malykh SB, Torgersen AM (eds.) (2008): Gene. Brain. Behavior. Moscow: Russian Panorama Press.

Torgersen AMK (2004). Tvillinger og forholdet mellom dem. Oslo: Cappelen Akademisk forlag (In Norwegian).

Torgersen AMK (2006). Tvillinger i puberteten. Tidsskrift for ungdomsforskning, 6 (1): 25-45 (In Norwegian).

Torgersen AM, Grova B, Sommerstad R (2007). A pilot study of attachment patterns in adult twins. Attach Hum Dev, 9, 127-138.

Torgersen AM (2013). Forklaringer på individuelle forskjeller i tilknytningsmønstre hos barn og voksne. Tidsskrift for Norsk Psykologforening, 50, 16-22 (In Norwegian).

Torgersen AM, Grova B (2012). Twins' relationship in retrospect: Does zygosity matter? Abstracts for The $14^{\text {th }}$ International congress on twin studies and The $2^{\text {nd }}$ world congress on twin pregnancy (ISTS). Florence, Italy. In: Twin Res Hum Genet, 15, 2, 170-261.

van Dongen J, Slagboom PE, Draisma HHM, Martin NG, Boomsma DI (2012). The continuing value of twin studies in the omics era. Nature Rev Genet, 13, 640-653.

Wilson R (1983). The Louisville Twin-study: developmental synchronies in behavior. Child Dev, 54, 298-316.

Windle M, Lerner R (1986). Reassessing the dimensions of temperamental individuality across life span: The revised dimensions of temperament survey (DOTS-R). J Adolesc Res, 1, 213-230. 